\title{
Editorial
}

\section{Ship Dynamics}

\section{Spyros Hirdaris *(1) and Tommi Mikkola (1)}

School of Engineering, Maritime Technology Group, Aalto University, 02150 Espoo, Finland; tommi.mikkola@aalto.fi

* Correspondence: spyros.hirdaris@aalto.fi

Citation: Hirdaris, S.; Mikkola, T. Ship Dynamics. J. Mar. Sci. Eng. 2021, 9, 105. https://doi.org/10.3390/ jmse 9020105

Academic Editor: Tony Clare

Received: 18 January 2021

Accepted: 19 January 2021

Published: 20 January 2021

Publisher's Note: MDPI stays neutral with regard to jurisdictional claims in published maps and institutional affiliations.

Copyright: (c) 2021 by the authors. Licensee MDPI, Basel, Switzerland. This article is an open access article distributed under the terms and conditions of the Creative Commons Attribution (CC BY) license (https:// creativecommons.org/licenses/by/ $4.0 /)$.
More than a century-and-half ago, William Froude and his son Robert [1,2] conducted the first scientifically designed towing tank experiments using scaled ship models travelling in calm water and waves. Since then, advances in mathematics and technology led to the development of various methods for the assessment of the dynamic behavior of ships. Today it is recognized that continuous improvement of direct assessment methods validated by model experiments or full-scale measurements are the doctrine of naval architecture. Yet, as we enter the 2nd decade of the 21st Century the advent of goal-based regulations and the emergence of safe and sustainable shipping standards still confront our ability to understand the fundamentals and assure absolute ship safety in design and operations.

To instigate renewed interest on the well-rehearsed subject of ship dynamics, this Special Issue presents a collection of 12 high-quality research contributions with a focus on the prediction and analysis of the dynamic behavior of ships in a stochastic environment. The papers presented are co-authored by leading academics and practitioners from Europe, the Far East and USA. The contributions discuss recent developments on:

- Ship wave loads in confused seas, including nonlinear effects [3], steady state hydroelastic responses [4], sloshing [5] and slamming [6].

- Dynamic coupling and resonant phenomena associated with seakeeping performance of ships in wind and waves [5,7].

- $\quad$ Ship maneuvering in level ice, waves and open water conditions [8-11].

- Dynamic stability in waves $[12,13]$.

- Ship energy efficiency in abrupt wave conditions [14].

The methods presented use combined knowledge from theoretical hydrodynamics, computational aero/hydrodynamics, fluid/structural dynamics and their interactions, as well as results from model tests and full-scale measurements. Strong emphasis is attributed on understanding nonlinearities and flow dissipation associated with stochastic responses in confused seas.

Based on these independent contributions it may be concluded that contemporary developments will be influenced by new science at the interface of multifield problems and the implementation of improved design criteria in advanced decision support systems. We therefore hope that this Special Issue will renew the interest of academics, practitioners and regulators in their pursuit to push forward ship science, technical services and safety standards of relevance.

Author Contributions: S.H. and T.M. wrote and reviewed this editorial. Both authors read and agreed to the published version of the manuscript.

Funding: S.H. acknowledges the support of the Academy of Finland under university competitive funding award (SA Profi 2-T20404).

Institutional Review Board Statement: Not applicable.

Informed Consent Statement: Not applicable.

Data Availability Statement: No new data were created or analyzed in this study. 
Conflicts of Interest: The authors declare no conflict of interest.

\section{References}

1. Froude, W. The Papers of William Froude; Institution of Naval Architects: London, UK, 1955.

2. The Royal Institution of Naval Architects. In Proceedings of the William Froude Conference: Advances in Theoretical and Applied Hydrodynamics-Past and Future, Organised by RINA, Lloyd's Register, Qinetiq and CD Adapco, Portsmouth, UK, 24-25 November 2010; ISBN 978-1-905040-77-3.

3. Ley, J.; el Moctar, O. A comparative study of computational methods for wave-induced motions and loads. J. Mar. Sci. Eng. 2021, 9, 83. [CrossRef]

4. Tilander, J.; Patey, M.; Hirdaris, S. Springing analysis of a passenger ship in waves. J. Mar. Sci. Eng. 2020, 8, 492. [CrossRef]

5. Igbadumhe, J.-F.; Sallam, O.; Fürth, M.; Feng, R. Experimental determination of non-linear roll damping of an FPSO pure roll coupled with liquid sloshing in two-row tanks. J. Mar. Sci. Eng. 2020, 8, 582. [CrossRef]

6. Chen, L.; Wang, Y.; Wang, X.; Cao, X. 3D Numerical simulations of green water impact on forward-speed wigley hull using open source codes. J. Mar. Sci. Eng. 2020, 8, 327. [CrossRef]

7. Bigi, N.; Roncin, K.; Leroux, J.-B.; Parlier, Y. Ship towed by kite: Investigation of the dynamic coupling. J. Mar. Sci. Eng. 2020, 8, 486. [CrossRef]

8. Suominen, M.; Li, F.; Lu, L.; Kujala, P.; Bekker, A.; Lehtiranta, J. Effect of maneuvering on ice-induced loading on ship hull: Dedicated full-scale tests in the Baltic Sea. J. Mar. Sci. Eng. 2020, 8, 759. [CrossRef]

9. Ren, Z.; Wang, J.; Wan, D. Investigation of the flow field of a ship in planar motion mechanism tests by the vortex identification method. J. Mar. Sci. Eng. 2020, 8, 649. [CrossRef]

10. Liu, S.; Papanikolaou, A. Prediction of the side drift force of full ships advancing in waves at low speeds. J. Mar. Sci. Eng. 2020, 8, 377. [CrossRef]

11. Nam, B.W. Numerical investigation on nonlinear dynamic responses of a towed vessel in calm water. J. Mar. Sci. Eng. 2020, 8, 219. [CrossRef]

12. Kapsenberg, G.; Wandji, C.; Duz, B.; Kim, S. A comparison of numerical simulations and model experiments on parametric roll in Irregular Seas. J. Mar. Sci. Eng. 2020, 8, 474. [CrossRef]

13. Acanfora, M.; Balsamo, F. The smart detection of ship severe roll motions and decision-making for evasive actions. J. Mar. Sci. Eng. 2020, 8, 415. [CrossRef]

14. Sun, C.; Wang, H.; Liu, C.; Zhao, Y. Dynamic prediction and optimization of energy efficiency operational index (EEOI) for an operating ship in varying environments. J. Mar. Sci. Eng. 2019, 7, 402. [CrossRef] 